\title{
E \\ Identifying successful marketing strategies by export regional destination
}

\author{
Nora Lado and Ester Martínez Ros \\ Department of Business Economics, Universidad Carlos III de Madrid, \\ Madrid, Spain, and \\ Ana Valenzuela \\ College of Business, San Francisco State University, San Francisco, \\ California, USA
}

Keywords International business, Markets, Export markets, Exports

\begin{abstract}
This study develops a model that explains export sales volume by destination based on a company's export marketing strategy. A seemingly unrelated regression model (SURE) simultaneously estimates the explanatory value of the different elements of the marketing strategy, as well as company characteristics, such as experience, size and motivation to export, on entry decisions to six different regional markets made by exporting companies in a southern European country. The data were collected from a sample size of 2,264 exporting companies. Findings confirm the importance of exporting experience and proactiveness in determining high export sales volumes in every regional market except for those psychologically close. Nevertheless, different marketing strategies depending on the region lead to high export sales volumes. For example, low price strategies in the case of Latin America or differentiation strategies based on the augmented product in the case of the USA generate high export sales. Promotional expenditures are of higher importance for distant markets, but for closer markets channel development is the key.
\end{abstract}

\section{Introduction}

Exporting represents one of the most common entry modes to international markets. As a consequence, exporting and export behavior have been a primary area of interest in the international marketing field and the focus of extensive marketing literature (Aaby and Slater, 1989; Bilkey, 1978; Cavusgil and Nevin, 1981; Douglas and Craig, 1992; Leonidou, 1995, 1998; Leonidou and Katsikeas, 1996). However, the majority of empirical studies in this area give little attention to the effect of export destination on export behavior and performance (Katsikeas, 1994). This study analyses export performance determinants in different regions using data from exporting companies in a Southern European country. Conducting this kind of research will help refine our understanding about how the strategy-performance relationship depends on the environmental context (Katsikeas et al., 2000). It will also allow us to assess the reliability and generalizability of past findings.

All the authors have an equal participation in the project. Their last names are in alphabetical order. The authors acknowledge the funds of Spanish project SEC2000 0395. They also wish to thank Gerardo Ungson and three anonymous reviewers for their helpful comments on earlier versions of the paper, and the Instituto Español de Comercio Exterior for providing access to the dataset. 
Past research has established that companies select foreign markets according to their attractiveness and perceived risk (Cavusgil and Zou, 1994). Once foreign target markets are selected, successful entry depends on how well export marketing strategies are formulated and implemented in order to match the firm's strategic strengths with market opportunities, or to neutralize the firm's strategic weaknesses to overcome market threats. In other words, the ability to meet foreign customer requirements effectively determines export performance levels (Katsikeas, 1994). Consequently, foreign market characteristics should pose both opportunities and threats for exporting firms that influence their marketing strategy.

Therefore, the key decision companies have to make in terms of their export marketing strategy is the level of standardization or adaptation to the local conditions (Douglas and Craig, 1989). An appropriate level of market adaptation is a key determinant of market performance. At the same time, the need for adaptation is conditioned by the degree of difference between countries (Cavusgil et al., 1993). These differences could be structural (e.g. different channels of distribution), consumer-based (e.g. different responses to product offerings) or cost-based (e.g. different transportation and communication costs).

These kinds of differences have been extensively studied in the literature using the concepts of geographic and psychic (or psychological) distance (O'Grady and Lane, 1996; Ghemawat, 2001). Geographic distance influences the level of cost necessary to establish an operation in a particular country (Dow, 2000). Psychological distance represents a collection of factors that inhibit the effective flow of information between a firm and its foreign target markets (Johanson and Vahlne, 1977) or that prevent firms from understanding a foreign environment (Nordstrom, 1991). Large geographic distances may contribute to large psychological distances, but the overall construct is substantially more complex (Dow, 2000). Recent operationalizations of psychic distance have put a lot more emphasis on cultural differences between countries, i.e. differences in language, religion, education, and political and legal systems (Dow, 2000; Klein and Roth, 1990). Culture influences many day-to-day decisions that people make, including purchase decisions (Conway and Swift, 2000). Therefore, psychological distance should condition a company's expansion strategy into overseas markets (Stöttinger and Schlegelmilch, 1998).

Nevertheless, this effect of physic distance is moderated by certain company characteristics. Dow (2000) found support for a company's international experience reducing the effect of psychological distance on export market selection. Additionally, Brouthers and Brouthers (2001) and Kogut and Singh (1988) established that company size influences how psychological distance conditions channel choice. Finally, Gripsrud (1990) identified export proactiveness as an additional variable acting in the relationship between psychic distance and attitude towards future exports.

The purpose of this paper is to investigate the relationship between export sales volume in each of a firm's export target-regions and the company's marketing strategy. Very few studies in the literature have attempted to cover a broad geographic area (Leonidou et al., 2002). Therefore, this kind of study does not have an extensive prior literature in which to support our hypothesis. We, thus, draw mainly on the literature about strategic and company determinants of export performance, which is usually tested in one regional market. Additionally, we aim at analyzing the moderating effect of company characteristics on the relationship between psychological distance and 
performance by region. Company characteristics considered in this study are company size, international experience and export proactiveness.

Nevertheless, most of the studies on marketing strategy determinants of export performance have focused on US exporters with little empirical evidence obtained from Europe (apart from the UK). Within Europe, the Spanish export share has increased by nearly 200 per cent in the last two decades and has reached seventh place in the ranking of leading exporters of merchandise trade in 2001 (WTO, 2002). In the context of our study, the case of Spanish exporting companies is of particular interest since it exemplifies very well a situation in which exporting companies have to decide on the level of involvement and marketing strategies to follow in regions perceived to be at a different physical and psychological distance. For example, Spanish exporting companies would consider Western Europe as physically close but psychologically more distant, and Latin America as more culturally close but a more physically distant export region. Finally, extensions of previous studies in new contexts, such as the one provided by Spanish exporting companies, are fundamental in the advancement of scientific disciplines in general and the marketing field in particular (Hubbard and Armstrong, 1994; Hubbard et al.., 1998).

In this paper, we use the body of literature developed by Cavusgil and Zou (1994), Aaby and Slater (1989) and Katsikeas et al. (2000) as the conceptual starting point for our empirical research. This literature is used to propose a model that explains level of performance in the different export regions based not only on export product, pricing, distribution, and promotional strategy, but also on company characteristics such as size, international experience and export proactiveness. Finally, we discuss the results of the model and propose additional related questions for future research.

\section{Conceptual framework and hypothesis development}

June and Collins-Dodd (2000) argue that research on exporting behavior evolves around three paradigms: the resource-based paradigm, the contingency paradigm and the relational paradigm.

The resource-based paradigm suggests that firm-level activities are determinants of a firm's export propensity. This stream of research has examined the influence of firm size, firm experience, firm competencies and marketing strategies on export performance (Aaby and Slater, 1989; Cavusgil and Zou, 1994; Styles and Ambler, 1994; Zou and Stan, 1998).

A second approach, the relational paradigm, focuses on the network of business interactions and views export expansion as the sequential development of relationships with other firms (Styles and Ambler, 1994).

Finally, the contingency paradigm considers that variables such as industry and market conditions are expected to mediate the influence of the various firm characteristics, strategies, and/or competencies with regard to export performance (Cavusgil and Zou, 1994; Reid, 1981; Yeoh and Jeong, 1995). Their main research hypothesis states that no strategy can be effective in all contexts. The effect of various firm characteristics and strategy on export performance depends on specific situational variables. These effects form also our main underlying premise.

The literature has identified situational variability between markets using the concept of geographic and psychic distance to foreign entry markets. Geographic distance is a strong indicator of the influence of transportation costs and 
communication difficulties in international decisions. Nevertheless, it cannot account for all situational variability between markets (Dow, 2000). The relation between cultural proximity and foreignness can be best mapped by the construct of psychic distance (Stöttinger and Schlegelmilch, 1998). In a recent article, Dow (2000) finds that psychic distance, as the set of factors that impede the effective flow of information between a firm and its foreign target markets (Johanson and Vahlne, 1977) or that prevent firms from understanding a foreign environment (Nordstrom, 1991), has a significant influence on export market selection. Therefore, the degree of similarity or dissimilarity to the home market renders some foreign target markets more attractive than others (Klein and Roth, 1990). We should expect perceived psychic distance between the domestic market and any foreign market to play a guiding role in country selection and strategic decisions during internationalization.

Research on psychic distance has been developed at a national level. Many researchers have chosen to use scales based on Sethi's (1971) clustering of world markets or Hofstede's (1980) cultural difference dimensions. Nevertheless, both of these scales fail to include differences in language, religion, education, political and legal systems, or levels of industrial development. Other empirical studies avoid these missing factors by asking an independent expert panel of managers to rate psychic distance (Nordstrom, 1991). Overall, psychic distance is a multifaceted construct, which is very difficult to capture (O'Grady and Lane, 1996; Steenkamp, 2001).

Nevertheless, recent operationalizations of psychic distance have put a lot more emphasis on country differences based on language, religion, education and political and legal systems (Dow, 2000; Klein and Roth, 1990). Ghemawat (2001) included the following variables as attributes that create cultural distance: "dissimilarity between spoken and written language", "lack of connective ethnic or social networks", "different religions", "different social norms"; and as attributes that create administrative distance: "absence of colonial ties", "absence of political association", and "political hostility". Accordingly, we could confidently assume that the psychological gap between Latin America and Spain is smaller than between Spain and other market-regions considering the fact that Latin America and Spain have a common language, legal and historical background. On the other hand, geographic distance was defined by "physical remoteness", "lack of common borders", "weak transportation and communication links". Similarly, Western Europe would be the region geographically closest to the Spanish market.

\section{Hypothesis development}

Companies enter markets successively. They are assumed to begin their internationalization process in countries that evoke feelings of cultural and psychical proximity, i.e. markets they can understand easily (Johanson and Vahlne, 1990; Benito and Gripsrud, 1992). Once a company learns and builds experience from these early entries, it sequentially enters markets that are progressively further away (Van Den Bulcke, 1986). The main assumption behind this theory is that going abroad requires a cumulative learning process. Additionally, experiential knowledge improves the understanding of the export markets (Madsen, 1989) and enhances the probability of a successful export performance in uncertain markets (Aaby and Slater, 1989; Mitra and Golder, 2002). Therefore, the amount of experience necessary for success increases with the psychic distance from the country of destination (Dow, 2000). 
H1. A company's international experience leads to a significantly higher export sales volume in markets that are psychologically more distant.

The larger the firm, the greater its ability to invest in order to control the higher risk of operating in psychologically distant markets (Kogut and Singh, 1988). Agarwal and Ramaswami (1992) demonstrate that firm size influences mode selection, with larger firms preferring full-control entry modes. Differences in firm size are considered significant in explaining, both directly and indirectly, export behavior and performance (Aaby and Slater, 1989). The basic assumption is that important inputs needed for exporting are indivisible and that economies of scale favor larger firms. Overall, larger firms have more resources, which can be applied to new markets and are less sensitive to risk in market development (Brouthers and Brouthers, 2001). These factors facilitate the development of export competitive advantages (Katsikeas, 1994). Therefore, they will enter psychologically most distant markets sooner and with more aggressive strategies.

H2. Company size leads to significantly higher export sales volume in markets that are psychologically more distant.

Finally, Czinkota and Johnston (1981), Katsikeas and Piercy (1993) and June and Collins-Dodd (2000) used the categorization proactive/reactive in terms of a company's motivations to export in order to discern the strategic orientation of the firm. According to Czinkota and Johnston (1981), a proactive exporter performs better in terms of sales volume, follows more cohesive export marketing strategies, performs more firm's sales-seeking and information-seeking activities, and is more likely to be service oriented than are reactive firms. Prior studies have also reported that the motivation to export is a consistent predictor of strong export performance (Dean et al., 2000).

Given that firms become active exporters, i.e. show a continuous effort to increase their export activities, they will become increasingly involved in psychologically distant markets (Gripsrud, 1990). When managers are committed to an export venture, they carefully plan the entry and allocate sufficient managerial and financial resources (Diamantopoulos and Inglis, 1988). With formal planning and resource commitment, uncertainty is reduced and marketing strategy can be implemented effectively (Cavusgil and Zou, 1994; Aaby and Slater, 1989).

H3. Exporting proactiveness (or motivation) leads to significantly higher export sales volume in markets that are psychologically more distant.

Knowledge of perceived distance between the home country and foreign markets is of limited value if the findings do not identify those areas where strategies can be developed to combat the perceived differences (Evans et al., 2000).

Export marketing strategy is the means by which a firm responds to the interplay of internal and external forces to meet the objectives of the export venture (Cavusgil and Zou, 1994). Export marketing strategy variables refer essentially to the company export product, pricing, distribution and promotion, which are key to exporting success (Katsikeas et al., 2000). In international marketing, an important consideration is whether the marketing strategy should be standardized or adapted to foreign market characteristics (Cavusgil and Zou, 1994; Shoham, 1996). Product adaptation, promotion adaptation, channel development and competitive pricing strategies have been described as the means by which a firm's offerings adapt to fit the idiosyncrasies of 
foreign markets (Douglas and Craig, 1989; Cooper and Kleinschmidt, 1985; Kirpalani and Macintosh, 1980). In this respect, our hypothesis follows the contingency paradigm: marketing strategies that explain successful export performance will be different by country. Therefore, companies should not follow a standardized export strategy across all countries.

In terms of the product variable, multiple studies in the literature have associated product adaptation (design, service, quality) with export development and success (see the meta-analysis study of Leonidou et al. (2002)). Product adaptation is defined in terms of the degree to which the firm adapts its core and augmented products to accommodate differences in environmental forces, consumer behavior, usage patterns and competitive situations (Leonidou et al.., 2002). In this context, Katsikeas (1994) found that companies involved in relatively high levels of exporting attach greater importance to their firm's ability to adapt products to the characteristics of local markets.

Additionally, the literature has demonstrated a positive relationship between market-based pricing and profitability (Christensen et al., 1987; Shoham, 1996). Setting prices according to customer demand and competition improves a company's responsiveness to market conditions and environmental forces, and, as a result, increases the likelihood of success in that market (Leonidou et al., 2002; Louter et al., 1991). Nevertheless, Shoham (1996) suggests that other elements of pricing (i.e. currency, payment method, and security) work better when standardized across international markets. Finally, Cooper and Kleinschmidt (1985) and Katsikeas (1994) found that price-oriented strategies (especially low-price strategies) were common to many exporting firms as a means to attract large numbers of foreign customers. This pattern of results was identified mainly among firms selling to neighboring countries (Cooper and Kleinschmidt, 1985) and among firms from less-industrialized countries (Katsikeas and Piercy, 1990).

Therefore, product and price adaptation to local conditions are antecedents of strong export performance. Particularly, the cultural dimension of psychological distance affects people and the way they live their lives, influencing many day-to-day decisions that people make (Conway and Swift, 2000). Culture affects the way consumers shop. For example, American consumers demand to be treated with importance when they shop and ask for service (O'Grady and Lane, 1996). Studies conducted in Europe have stressed the positive influence of product quality on export performance in that region (Leonidou et al., 2002). On the other hand, the economic dimension of psychological distance affects what consumers can afford (Ghemawat, 2001). Specifically, Latin American consumers have been found to be more price-sensitive on average (Dominguez and Sequeira, 1993). Additionally, we expect that purchasing power dispersion in Europe will require adapting to each individual national market condition. Therefore, a mixed-price strategy should be most effective.

H4. The more distant a market is culturally, the more different are the product attributes that the foreign consumer values and, as a result, the greater effect product adaptation has on export sales volume.

The particular context under which these hypotheses are tested covers Latin America, Europe and the USA. Specifically, we expect that when companies export to the USA, consumer cultural differences will make marketing strategies based on augmenting the 
product through additional service more important to increase export sales volume. On the other hand, when a company desires to export to Europe, consumer cultural differences will make marketing strategies based on enhanced product quality more important to increase export sales volume.

H5. The more distant a market is economically, the more different consumer price sensitivities are, therefore, the more price adaptation increases export sales volume.

We test this hypothesis in the context of Spanish exporting companies. Specifically, we expect that when exporting to Latin America, consumer price sensitivity differences will make marketing strategies based on lower prices increase export sales volume more significantly. Finally, when exporting to Europe, consumer price sensitivity differences will make a mixed-price strategy increase export sales volume more significantly.

In most cases, the literature has confirmed a positive relationship between the company's communication strategy adaptation and performance (Leonidou et al., 2002; Shoham, 1996; Cavusgil et al., 1993). Specifically, past research consistently found a strong positive influence of advertising expenditure on export performance regardless of export destination (Burton and Schlegelmilch, 1987; Fraser and Hite, 1990). On the other hand, Amine and Cavusgil (1986) consider the role of personal contacts crucial within the communication strategy of exports. In their study, although exporters used local media, promotional instruments, and trade and point-of-sale advertising, all of these were judged as secondary. For example, trade fairs offer the possibility of testing the market, finding distributors, and accessing information about export market potential and customer requirements (Leonidou et al.., 2002; Seringhaus and Rosson, 1998). These tasks are particularly important for distant markets, which are more difficult to monitor or to stay in contact with current and potential consumers. We should, then, find a stronger influence of this kind of promotional elements on export sales in geographically distant markets.

Finally, previous research has also found distribution strategies, including the use of intermediaries and strategic partnerships, related to export success (Aaby and Slater, 1989; Cavusgil and Zou, 1994; June and Collins-Dodd, 2000). Since the appropriateness of a particular distribution channel depends on variable market environments and distribution infrastructures (Leonidou et al., 2002), successful exporters particularly stress the importance of ongoing distribution relationships, dealer support, and frequent visits to foreign representatives (Beamish et al., 1993; Cavusgil and Zou, 1994). Geographical proximity should facilitate personal sales contact (Shenkar, 2001), lower the costs of managerial coordination and control, and reduce the cost of monitoring an agent's behavior. Cooperation in the export channel will lead to effective implementation of the marketing strategy and better performance (Rosson and Ford, 1982). Therefore, channel development should have a stronger effect on export sales in geographically closer markets.

H6. Advertising expenditure will improve export sales volume regardless of market distance.

H7. Personal contacts, such as participation in fairs and direct-to-consumer communication tools, will improve export sales volume more significantly in 
geographically distant markets (e.g. Latin America in the context of Spanish exporting companies).

H8. Channel development will improve export sales more significantly in geographically closer markets (e.g. Europe in the context of Spanish exporting companies).

\section{Methodology and sample \\ Sources of data}

The primary source of data for the analysis is a survey of Spanish exporting companies conducted by the Spanish Chamber of Commerce (Instituto Español de Comercio Exterior) in 1998. The survey's population included every Spanish exporting company within the most important manufacturing and agricultural industries $(13,601$ enterprises). A sample size of 2,264 companies allowed for a 95.5 per cent significance level, a 2.1 per cent error level in the entire sample and a 10 per cent error level by segments. Therefore, a stratified random sampling by industry and company size was used to ensure adequate representation. Data were collected through in-depth personal interviews with export managers conducted by a professional market research firm to achieve a higher rate of respondent participation. We have to take into consideration that the population was defined using the universe of companies that had declared themselves an exporter, not of companies that could potentially be exporters. Hence, the database could suffer from selection bias.

Food, beverages and tobacco, textile products and metallic products were the most active industries in terms of exporting activity. Additionally, 83.39 per cent of the firms surveyed could be considered small and medium-sized with less than 200 workers. The primary export destination was the European Union (94 per cent of Spanish exporting firms) followed by Latin America (43 per cent of Spanish exporting firms). Other destinations are listed in order of importance: Asian-Pacific (37 per cent), rest of Europe (35 per cent), USA/Canada (34 per cent). Only 17 per cent of the firms had foreign capital participation.

The survey included information on performance - sales, profitability, growth organizational structure - departments, employment, outsourcing, training - R\&D

activities, and marketing strategy. This study will specifically work with variables related to marketing strategy.

\section{Methodology}

Our quantitative analysis shares many settings of estimation models such as capital asset pricing or demand systems. In the case of these models, it is possible to apply a simultaneous estimation process to a group of related variables. In terms of our research, our initial assumption is that firms produce and sell their products to different geographical regions using different marketing policies. Therefore, we will apply that same methodology to be able to estimate simultaneous equations that explain degree of performance in the different regional markets depending on firm characteristics, strategic behavior and marketing plans.

The procedure applied is called seemingly unrelated regressions model (SURE) and it consists of a common multiple equation structure, which we could write as: 


$$
\begin{array}{ll}
y_{1} & X_{1} \beta_{1}+\varepsilon_{1} \\
y_{2} & X_{2} \beta_{2}+\varepsilon_{2} \\
\cdot & \\
\cdot & \\
\cdot & \\
y_{m} & X_{m} \beta_{m}+\varepsilon_{m}
\end{array}
$$

There are $m$ equations and $T$ observations in the data sample. The error term is normally distributed with 0 mean and $\sigma$ variance. Disturbances are uncorrelated across observations.

Seemingly unrelated regression models are so called because they appear to be joint estimates of several regression models, each with its own error term. The regressions are related because the contemporaneous errors associated with the dependent variables may be correlated. Each equation is, by itself, a classical regression. Therefore, the parameters could be estimated consistently, if not efficiently, by ordinary least squares. Nevertheless, the efficient estimator is generalized least squares, which applies to the stacked model. In fact, the greater the correlation of the disturbances and the less correlation there is between the $\mathrm{X}$ matrices, the greater the efficiency gain accruing generalized least squares.

We apply this estimation procedure to explain why companies have a particular level of export sales volume in different regional markets. The explanatory variables are: motivation to export, company size, experience in foreign markets, and components of the marketing strategy. In the estimation procedure, we include a dummy per industry type in order to control for heterogeneous effects due to production markets (see Table I for descriptive information on the values of these dummies).

\section{Variable operationalization}

Dependent and independent variables included in the model are instrumented as

\begin{tabular}{|c|c|c|c|}
\hline Industry & Mean & Std. Dev. & \\
\hline Agriculture & 0.0293561 & 0.1688825 & \\
\hline Food, beverages & 0.0833333 & 0.2765164 & \\
\hline Textile products & 0.1950758 & 0.3964468 & \\
\hline Wood & 0.0625000 & 0.2421762 & \\
\hline Paper & 0.0350379 & 0.1839627 & \\
\hline Other manufactures & 0.2717803 & 0.4450880 & \\
\hline High tech & 0.1079545 & 0.3104700 & \\
\hline Automobiles and vehicles & 0.0719697 & 0.2585602 & Table I. \\
\hline Extractive products & 0.0198864 & 0.1396759 & Industry dummies \\
\hline Construction & 0.0113636 & 0.1060432 & descriptives \\
\hline
\end{tabular}
follows (see Table II for an explanation of measurement scales and references to other sources in the literature that addressed them): 


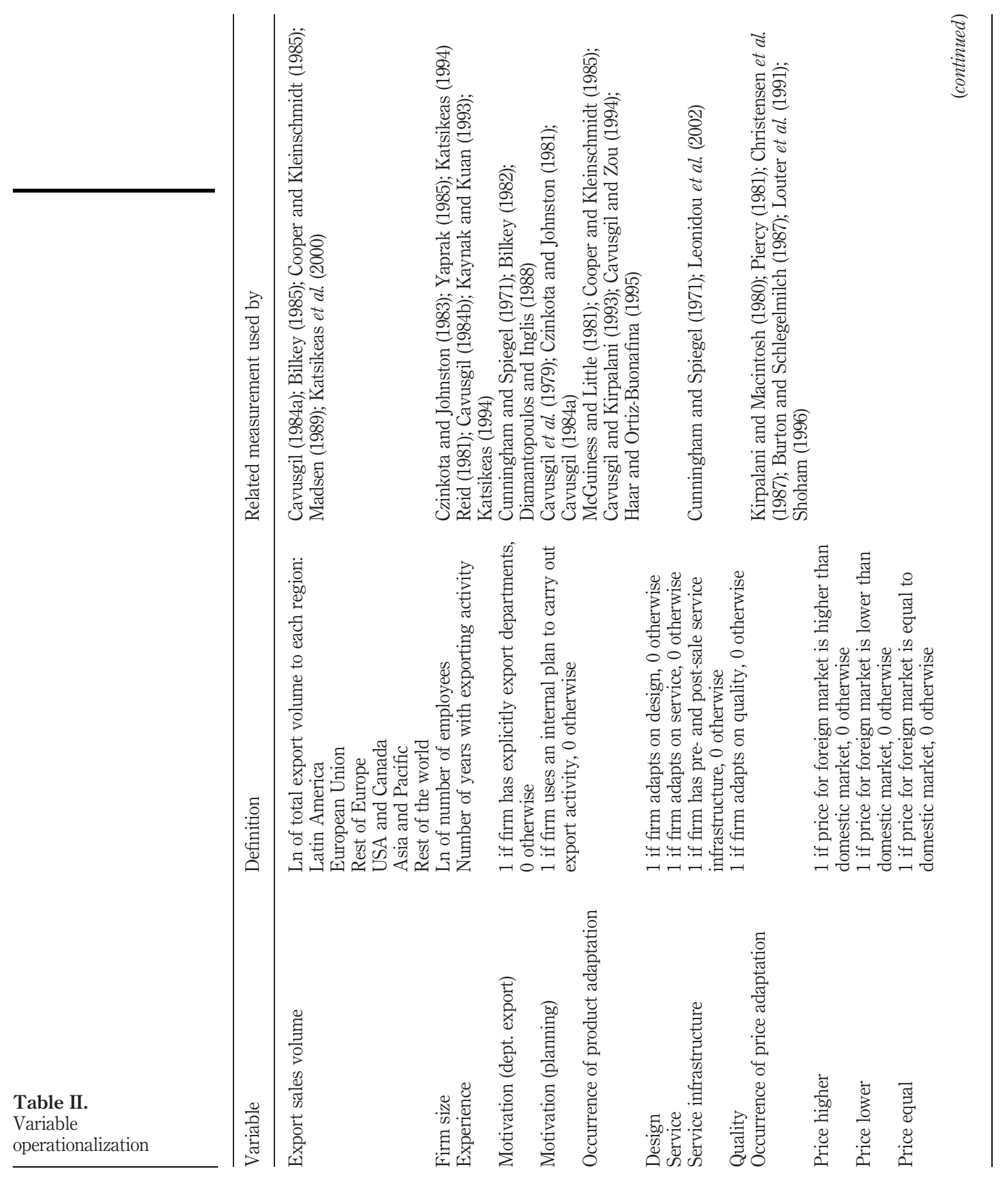




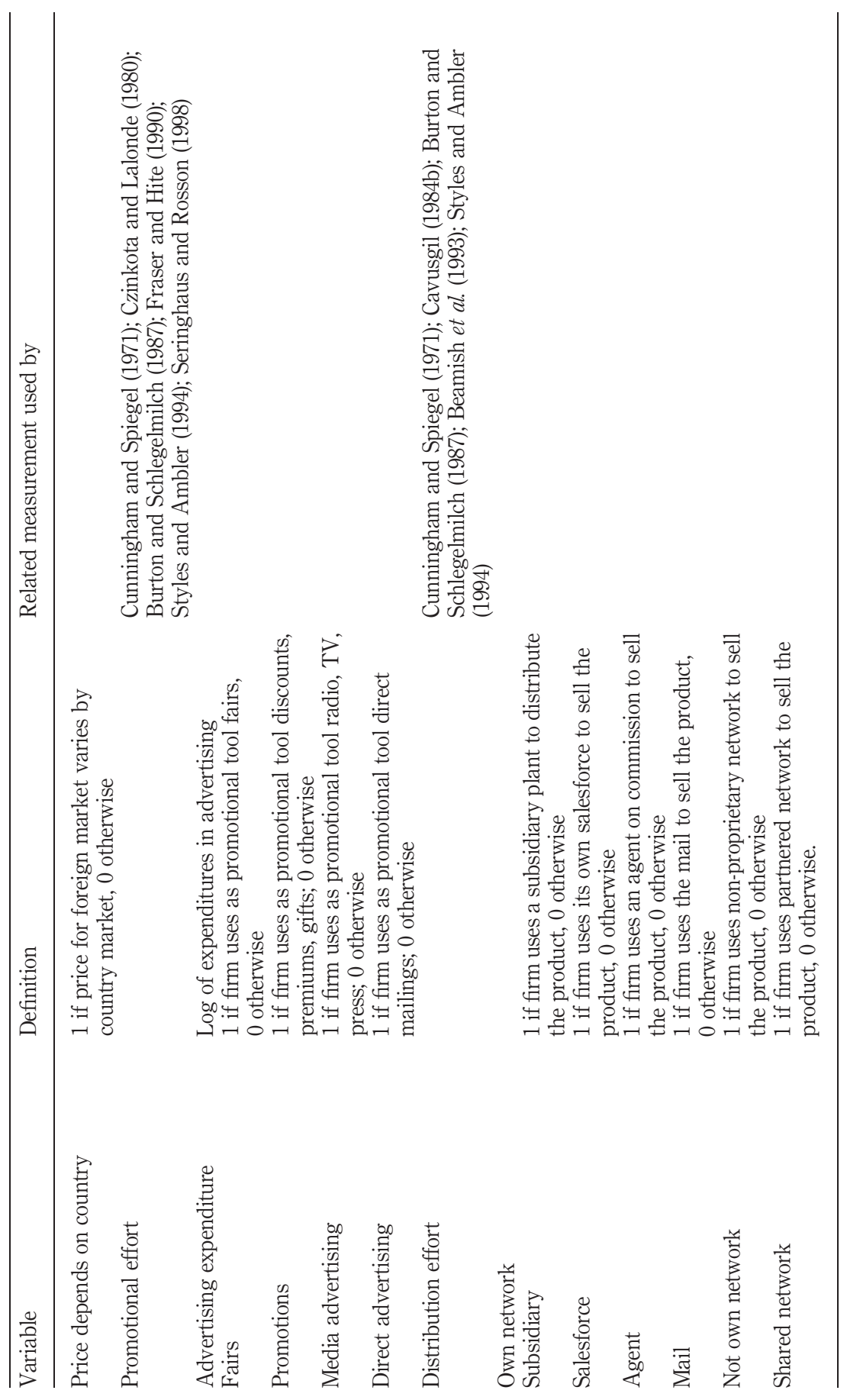

Table II. 
Dependent variable: export sales volume. We use total export volume to a particular region expressed in logarithms as our dependent variable. One of the most frequently used sales-related measurements of exporting outcomes is export sales volume. Even though export performance is a multidimensional construct, sales-related measures have been used most often to represent export performance (Katsikeas et al., 2000). It emphasizes effectiveness (achievement of sales goals) and adaptiveness (ability to respond to environmental changes) as dimensions of performance (Katsikeas et al., 2000). Export sales volume also has the advantage of being an objective measurement of the success of a company in a particular export destination. Multiple studies have used this dependent variable in the past (e.g. Cavusgil, 1984a; Bilkey, 1985; Cooper and Kleinschmidt, 1985; Madsen, 1989).

Independent variables: firm size. As most indicators of firm size are likely to be correlated (Gupta, 1980), we use total number of employees to measure company size. We suspect a smaller response bias in this survey question than in other traditional measurements of firm size such as total sales or total assets (Katsikeas, 1994). Specifically, we used the log of number of employees as a measurement of firm size.

Firm experience. Firm experience has traditionally been measured by the number of years the company has been engaged in exporting (e.g. Reid, 1981; Cavusgil, 1984b; Katsikeas, 1994; Kaynak and Kuan, 1993). We use the same measurement of firm experience in our study.

Firm export motivation. We distinguished between motivating factors that are proactive in contrast with those that are reactive. Czinkota and Johnston (1981) identified planning of the export activity as a signal of proactive export motivation. We incorporate this variable as a dummy equal to 1 if the company performs export strategic planning, and zero if the company only reacts to demand cycles, orders, etc. instead of considering exporting as part of the strategic orientation of the firm.

We also incorporated the company's export motivation by creating a variable that showed the existence of an export department. The existence of an export department is a sign of long-term investment in export infrastructure. Several studies have already used this measurement of export motivation in the literature (e.g. Cunningham and Spiegel, 1971; Bilkey, 1982; Diamantopoulos and Inglis, 1988).

Marketing strategies. We incorporate the company's marketing strategy into the model by codifying whether or not the company has implemented the marketing elements identified in the literature as determinant of export performance. We applied past literature findings by marketing element using variables that assigned the value of 1 if that element had been implemented by the company as part of its marketing strategy or the value of 0 if it had not. This information was available at the firm level. We classified these elements in terms of product-based, price-based, promotion-based, and distribution-based strategies. These elements are:

(1) Product/service:

- Is there product adaptation in terms of product quality and/or design and/or service (e.g. McGuiness and Little, 1981; Cooper and Kleinschmidt, 1985; Cavusgil and Kirpalani, 1993; Cavusgil and Zou, 1994; Haar and Ortiz-Buonafina, 1995)?

- Is there investment in pre- and post-sale service infrastructure (e.g. Cunningham and Spiegel, 1971; Leonidou et al.., 2002)? 
(2) Pricing: what is the difference in price level among foreign and domestic markets? Here, we differentiate between whether the price is high, equal or low in relation to the domestic market or whether it depends on the country of destination, i.e. a market-based pricing strategy (e.g. Kirpalani and Macintosh, 1980; Piercy, 1981; Christensen et al., 1987; Burton and Schlegelmilch, 1987; Louter et al., 1991; Shoham, 1996).

(3) Promotion:

- What is the company's total expenditure in advertising (log of expenditures in advertising) (e.g. Burton and Schlegelmilch, 1987; Fraser and Hite, 1990)?

- What elements within the promotional strategy were implemented in foreign markets: fairs and/or direct mailings and/or promotions (e.g. Czinkota and Lalonde, 1980; Styles and Ambler, 1994; Seringhaus and Rosson, 1998)?

(4) Distribution/place: what is the type of channel network used by the company for its distribution strategy? Here, we differentiate among proprietary networks, non-proprietary networks, and partnered networks (e.g. Cunningham and Spiegel, 1971; Cavusgil, 1984b; Burton and Schlegelmilch, 1987; Beamish et al., 1993; Styles and Ambler, 1994).

\section{Results}

Our model provides estimates of the influence of company characteristics and marketing strategies on export sales volume of Spanish companies by destination. Tables III to VIII show the model's coefficients. Our estimation technique provides a significant level of $R^{2}$ in all equations.

\begin{tabular}{lcccccc}
\hline Equation & Obs & Parm & RMSE & $R^{2}$ & $F$ & $P$ \\
\hline Latin America & 1,056 & 31 & 3.708326 & 0.5974 & 49.06237 & 0.0000 \\
European Union & 1,056 & 31 & 2.431819 & 0.9334 & 46.37483 & 0.0000 \\
Rest of Europe & 1,056 & 31 & 3.604933 & 0.5130 & 34.83596 & 0.0000 \\
USA and Canada & 1,056 & 31 & 3.696297 & 0.4762 & 30.05408 & 0.0000 \\
Asian Pacific & 1,056 & 31 & 3.752077 & 0.5208 & 35.93845 & 0.0000 \\
Rest of the World & 1,056 & 31 & 3.851108 & 0.5674 & 43.36513 & 0.0000 \\
\hline & & & & & & \\
& & & & & \\
& Latin & European & Rest of & USA and & Asia and & Rest of the \\
& America & Union & Europe & Canada & Pacific & World \\
\hline Employment & 0.644 & 0.837 & 0.554 & 0.409 & 0.480 & 0.774 \\
& $(6.877)^{\mathrm{a}}$ & $(13.640)$ & $(6.090)$ & $(4.388)$ & $(5.067)$ & $(7.964)$ \\
Experience & 0.003 & 0.021 & 0.020 & 0.038 & 0.022 & 0.007 \\
& $(0.796)$ & $(7.759)$ & $(5.085)$ & $(9.336)$ & $(5.199)$ & $(1.848)$ \\
Dept. Export & 0.505 & 0.546 & 0.555 & 0.588 & 0.801 & 0.652 \\
& $(1.871)$ & $(3.085)$ & $(2.114)$ & $(2.184)$ & $(2.933)$ & $(2.325)$ \\
Planning & 0.256 & 0.350 & 0.370 & 0.230 & 0.624 & 0.035 \\
& $(0.906)$ & $(1.890)$ & $(1.349)$ & $(0.816)$ & $(2.183)$ & $(0.119)$
\end{tabular}

Notes: ${ }^{\mathrm{a}} t$ student values are in brackets; the number between parentheses is a $t$ statistic $(t>2, p<0.05)$

Table IV. Organizational variables
Table III. SURE results 


\begin{tabular}{|c|c|c|c|c|c|c|c|}
\hline & & $\begin{array}{c}\text { Latin } \\
\text { America }\end{array}$ & $\begin{array}{l}\text { European } \\
\text { Union }\end{array}$ & $\begin{array}{l}\text { Rest of } \\
\text { Europe }\end{array}$ & $\begin{array}{l}\text { USA and } \\
\text { Canada }\end{array}$ & $\begin{array}{c}\text { Asia and } \\
\text { Pacific }\end{array}$ & $\begin{array}{l}\text { Rest of the } \\
\text { World }\end{array}$ \\
\hline & $\begin{array}{l}\text { Quality } \\
\text { Services } \\
\text { Design } \\
\text { Infrastructure }\end{array}$ & $\begin{array}{c}0.340 \\
(0.555) \\
0.196 \\
(0.318) \\
0.391 \\
(0.876) \\
0.430 \\
(1.651)\end{array}$ & $\begin{array}{c}0.513 \\
(1.278) \\
0.023 \\
(0.056) \\
0.132 \\
(0.451) \\
0.242 \\
(1.414)\end{array}$ & $\begin{array}{c}1.109 \\
(1.870) \\
0.404 \\
(0.676) \\
1.080 \\
(2.498) \\
0.447 \\
(1.773)\end{array}$ & $\begin{array}{c}0.596 \\
(0.978) \\
1.630 \\
(2.655) \\
0.613 \\
(1.378) \\
0.082 \\
(0.315)\end{array}$ & $\begin{array}{c}0.232 \\
(0.375) \\
0.335 \\
(0.537) \\
0.006 \\
(0.014) \\
0.324 \\
(1.231)\end{array}$ & $\begin{array}{c}1.153 \\
(1.815) \\
0.119 \\
(0.186) \\
0.691 \\
(1.492) \\
0.272 \\
(1.007)\end{array}$ \\
\hline \multirow[t]{3}{*}{$\begin{array}{l}\text { Table V. } \\
\text { Product policy }\end{array}$} & \multicolumn{7}{|c|}{$\begin{array}{l}\text { Notes: }{ }^{\mathrm{a}} t \text { student values are in brackets; the number between parentheses is a } \\
t \text { statistic }(t>2, p<0.05)\end{array}$} \\
\hline & Differences if & $\begin{array}{c}\text { Latin } \\
\text { America }\end{array}$ & $\begin{array}{l}\text { European } \\
\text { Union }\end{array}$ & $\begin{array}{l}\text { Rest of } \\
\text { Europe }\end{array}$ & $\begin{array}{l}\text { USA and } \\
\text { Canada }\end{array}$ & $\begin{array}{l}\text { Asia and } \\
\text { Pacific }\end{array}$ & $\begin{array}{l}\text { Rest of the } \\
\text { World }\end{array}$ \\
\hline & $\begin{array}{l}\text { Price is higher } \\
\text { Price is lower } \\
\text { Price is equal } \\
\text { Depending on } \\
\text { country }\end{array}$ & $\begin{array}{c}1.763 \\
(1.914) \\
1.943 \\
(2.071) \\
0.998 \\
(1.081) \\
1.638 \\
(1.774)\end{array}$ & $\begin{array}{c}2.414 \\
(4.003) \\
2.361 \\
(3.841) \\
2.589 \\
(4.283) \\
2.335 \\
(3.859)\end{array}$ & $\begin{array}{c}0.527 \\
(0.589) \\
0.364 \\
(0.399) \\
0.485 \\
(0.542) \\
0.083 \\
(0.092)\end{array}$ & $\begin{array}{c}0.727 \\
(0.793) \\
0.330 \\
(0.353) \\
0.772 \\
(0.840) \\
0.742 \\
(0.807)\end{array}$ & $\begin{array}{c}0.010 \\
(0.010) \\
0.407 \\
(0.428) \\
0.254 \\
(0.272) \\
0.616 \\
(0.659)\end{array}$ & $\begin{array}{c}1.608 \\
(1.682) \\
0.531 \\
(0.545) \\
1.697 \\
(1.771) \\
0.202 \\
(0.211)\end{array}$ \\
\hline $\begin{array}{l}\text { Table VI. } \\
\text { Price policy }\end{array}$ & \multicolumn{7}{|c|}{$\begin{array}{l}\text { Notes: }{ }^{\mathrm{a}} t \text { student values are in brackets; the number between parentheses is a } \\
t \text { statistic }(t>2, p<0.05)\end{array}$} \\
\hline
\end{tabular}

Table VII.

Promotion policy

\begin{tabular}{lcccccc}
\hline & $\begin{array}{c}\text { Latin } \\
\text { America }\end{array}$ & $\begin{array}{c}\text { European } \\
\text { Union }\end{array}$ & $\begin{array}{c}\text { Rest of } \\
\text { Europe }\end{array}$ & $\begin{array}{c}\text { USA and } \\
\text { Canada }\end{array}$ & $\begin{array}{c}\text { Asia and } \\
\text { Pacific }\end{array}$ & $\begin{array}{c}\text { Rest of the } \\
\text { World }\end{array}$ \\
\hline \multirow{2}{*}{ Fairs } & 0.714 & 0.007 & 0.710 & 0.581 & 0.721 & 0.497 \\
& $(1.931)$ & $(0.028)$ & $(1.974)$ & $(1.576)$ & $(1.925)$ & $(1.295)$ \\
Promotions & 1.561 & 0.140 & 1.559 & 1.191 & 0.624 & 0.544 \\
& $(3.070)$ & $(0.421)$ & $(3.155)$ & $(2.351)$ & $(1.212)$ & $(1.031)$ \\
Media advertising & 0.272 & 0.252 & 0.212 & 0.748 & 0.067 & 0.198 \\
& $(0.815)$ & $(1.153)$ & $(0.655)$ & $(2.248)$ & $(0.199)$ & $(0.572)$ \\
Direct advertising & 0.818 & 0.022 & 0.425 & 0.223 & 0.496 & 0.348 \\
Advertising expenditure & $(2.617)$ & $(0.109)$ & $(1.398)$ & $(0.715)$ & $(1.568)$ & $(1.072)$ \\
& 0.167 & 0.090 & 0.137 & 0.107 & 0.173 & 0.168 \\
& $(3.197)$ & $(2.614)$ & $(2.697)$ & $(2.055)$ & $(3.266)$ & $(3.102)$
\end{tabular}

Notes: ${ }^{\mathrm{a}} t$ student values are in brackets; the number between parentheses is a $t$ statistic $(t>2, p<0.05)$ 


\begin{tabular}{ccccccc}
\hline & $\begin{array}{c}\text { Latin } \\
\text { America }\end{array}$ & $\begin{array}{c}\text { European } \\
\text { Union }\end{array}$ & $\begin{array}{c}\text { Rest of } \\
\text { Europe }\end{array}$ & $\begin{array}{c}\text { USA and } \\
\text { Canada }\end{array}$ & $\begin{array}{c}\text { Asia and } \\
\text { Pacific }\end{array}$ & $\begin{array}{c}\text { Rest of the } \\
\text { World }\end{array}$ \\
\hline Own network & & & & & & \\
Subsidiary & 0.036 & 4.243 & 0.168 & 2.415 & 2.011 & 1.323 \\
& $(0.025)$ & $(4.578)$ & $(0.122)$ & $(1.703)$ & $(1.396)$ & $(0.895)$ \\
Represent & 1.251 & 3.791 & 0.412 & 2.780 & 2.303 & 0.049 \\
& $(0.907)$ & $(4.224)$ & $(0.308)$ & $(2.024)$ & $(1.651)$ & $(0.034)$ \\
Agent & 1.235 & 3.934 & 0.581 & 2.644 & 1.651 & 0.415 \\
& $(0.902)$ & $(4.413)$ & $(0.436)$ & $(1.939)$ & $(1.192)$ & $(0.292)$ \\
Mail & 0.991 & 3.651 & 0.481 & 2.344 & 2.049 & 0.068 \\
& $(0.719)$ & $(4.069)$ & $(0.359)$ & $(1.707)$ & $(1.470)$ & $(0.048)$ \\
Not own & 0.227 & 3.633 & 0.457 & 2.348 & 2.102 & 0.432 \\
network & $(0.168)$ & $(4.135)$ & $(0.349)$ & $(1.746)$ & $(1.540)$ & $(0.308)$ \\
Sharing & 0.944 & 3.715 & 1.151 & 1.944 & 1.949 & 1.329 \\
network & $(0.664)$ & $(4.014)$ & $(0.833)$ & $(1.373)$ & $(1.355)$ & $(0.900)$
\end{tabular}

Notes: ${ }^{\mathrm{a}} t$ student values are in brackets; the number between parentheses is a $t$ statistic $(t>2, p<0.05)$

Table VIII. Place policy

In this context, one added value of our methodology is that a simultaneous equation model provides a more suitable inference of the results. Moreover, the control by industry provides robust results increasing the significance of parameters in some cases as, for example, the parameters related to price policy. In fact, the comparison of such results with those that could be obtained using an OLS method proves that we should not consider export destination decisions as independent of exporting sales volume. Export sales volume and export destinations are dependent on each other.

Table IV provides results that support the fact larger firms are more engaged in export activity. Results prove that size is significant in explaining export sales volume. These results are due to the amount of resources necessary to carry out a successful international operation. Additionally, we observe that the existence of an export department contributes to export sales volume and only large firms are capable of sustaining such a level of fixed costs.

On the other hand, exporting experience seems to affect export sales volume positively for all destinations except for Latin America and other minor destinations that are labeled "Rest of the world". This result could be explained by the fact that Latin American markets are culturally closer to Spanish exporting companies and are perceived as less threatening in terms of lack of knowledge and high perception of risk.

We also find positive results in the effect of the company's proactiveness or motivation towards exporting, i.e. considering exporting as a sustainable source of revenue included in the company's strategic plan. We used two different variables to measure proactive commitment to exporting. First, we used the existence or not of a formal exporting department and, second, the inclusion or not of exporting in the company's strategic planning. As already mentioned, the existence of an exporting department significantly explains a higher level of export sales volume in all regional markets except Latin America. This result supports the fact that Latin America, as a market destination, does not demand the same type of capabilities for Spanish exporting companies as would any other foreign market destination. 
Tables V to VIII include the result coefficients for each element of the marketing strategy. Results show that marketing strategy has an important impact on export sales volume. It confirms our main hypothesis of the existence of a significant relationship between a company's market destination and the exporting marketing strategy followed.

In terms of product strategy, our first hypothesis is confirmed. Product adaptation of the amount of service included in the product offering (augmented product) is highly discriminatory of export sales volume for the USA and Canada. On the other hand, we do not find support for our second hypothesis. Quality-based product adaptation does not explain larger sales volume to the European Union. This result may be due to the fact that products do not need to be adapted for extra quality since they are initially developed in a European country (Spain) and already have the required level of quality in consideration. Finally, we also find a result not hypothesized. Design-based product adaptation seems to be significant in explaining export sales volume in the rest of Europe, although with a negative effect.

With respect to the price strategy, results show that relative prices are only effective in increasing exports directed to Latin America and the European Union. As expected, export sales volume is highest when a company is able to offer prices that are competitive and in parity with that country's purchasing power. This means lowering prices for products offered to Latin America. In the case of the European Community, we find a positive coefficient for every type of price structure, which reveals price heterogeneity and acquisition power dispersion.

It is important to point out that we are referring to overall price levels. There are other elements of price standardization, such as currency, credit terms or pricing methods, that have been shown to have an effect on performance (Shoham, 1996) but that were not considered independently in this study.

Table VII includes the effect coefficients for the different variables that characterize promotional strategy. The expenditure in advertising has the expected effect on export activity. We find that advertising expenditure has an impact on export sales volume in every market destination, although the effect is larger in the case of exports directed to destinations geographically distant from Spain. In the case of exports directed to the European Union, the explanatory value of advertising expenditure, although significant, is lower than for geographical distant markets such as Latin America $(p<0.01)$. Likewise, other elements of the promotion mix, for example fairs, consumer promotions or direct marketing, do not have a positive effect on export sales volume for exporters to the European Union. They do, however, have a positive effect on those exports directed to Latin America, Asia and Rest of Europe in the case of fairs and for Latin America, Rest of Europe and USA-Canada in the case of consumer promotions, and only for Latin America in the case of direct marketing.

Finally, in terms of distribution channels, exports to the European Union benefit a great deal from developing a comprehensive distribution network, both proprietary and non-proprietary. For the rest of destinations, the positive effect of a distribution network does not hold.

\section{Discussion}

There is an extensive literature that aims at understanding the antecedents of export performance. The knowledge, however, is still far from being comprehensive. As 
derived from the review studies by Aaby and Slater (1989) and Zou and Stan (1998), a pattern of inconsistent and conflicting empirical findings still exists in the literature about the relative importance of export performance determinants. One of the reasons for this inconsistency is that models of export performance have traditionally been tested in one single target market (Katsikeas et al.., 2000). In this paper, we try to add to the literature by developing a model that includes firm characteristics (size, experience, commitment) and marketing strategy decisions (product, price, promotions and distribution) as explanatory of export sales volume, and testing it in six different regional markets. Conducting this kind of research would allow us to study the reliability and generalizability of past findings. It will also help refine our understanding about how the strategy-performance relationship depends on the environmental context (Katsikeas et al., 2000).

In this paper, we distinguished between antecedents of export performance by type of target market - physically distant/close or psychologically distant/close. In the case of Spanish exporting companies, the European Union is the region physically closest and Latin America the region psychologically closest. Our premise is that physical and psychological distances impede the effective flow of information between a firm and foreign target markets (Johanson and Vahlne, 1977) and prevent firms from understanding the foreign environment (Nordstrom, 1991). Therefore, both physical and psychological distances should have a significant influence on:

- export market selection;

- company's characteristics necessary for successful entry; and

- marketing strategy that precludes export success.

In terms of firm characteristics, our findings confirm that the impact of psychological distance declines as the firm gains international experience (Dow, 2000; Aaby and Slater, 1989). Consequently, exporting experience, although significant in most of the cases, was not important in explaining export sales volume in Latin America. The fact that the Latin American region is seen as psychologically close to Spain reduces the perceived risk of failure, and gives incentives to companies with a limited exposure to foreign markets to start trading with that area. Export commitment or proactiveness has also been linked in the literature to larger export sales (Czinkota and Johnston, 1981). Proactive firms seek information about new markets, plan their activity, and allocate sufficient resources to execute their plan (Gripsrud, 1990; Diamantopoulos and Inglis, 1988). Therefore, we should expect export proactive firms to do better in psychologically more distant markets. Confirming this hypothesis, our findings show that level of export commitment is only a significant explanatory value of sales for psychologically more distant markets. In fact, the most stringent measurement of export involvement, inclusion of exporting in the company's long term planning, was only a significant determinant of export sales in the psychologically most distant market, Asian and Pacific. On the other hand, company size does not seem to discriminate between export regions. Smaller firms have been found to be less capable of making necessary export market investments (promotional support, organizational support, assessment of export market development) to boost export sales due to their resource constraints (Katsikeas, 1994). Therefore, company size appears to be a requirement for involvement in any market. 
In terms of marketing variables, our findings show that the strategic determinants of export sales volume are different depending on the region of destination. Therefore, we confirm the effectiveness of an adapted marketing strategy to each market's specific conditions. Past research had already established the link between product adaptation (e.g. McGuiness and Little, 1981; Cavusgil and Kirpalani, 1993; Cavusgil and Zou, 1994), price adaptation (e.g. Kirpalani and Macintosh, 1980; Christensen et al., 1987; Louter et al., 1991) and export performance. Product adaptation reflects a customer orientation and forces the firm to evaluate buyer behavior and target market characteristics (Douglas and Wind, 1987). Price adaptation is crucial to ensure competitiveness in foreign target markets and can be the result of several different factors, especially important being the recognition of differences in consumer purchasing power (Louter et al., 1991). Nevertheless, past literature had not established which specific adaptations were necessary to increase sales to a particular export destination. Our findings confirm that product adaptation generally improves export sales volume, but requires identification of the right product element to adapt. The direction of price adaptation also differs with the region of export destination. For example, products targeted to the USA should be adapted by augmenting services, products targeted to Eastern Europe by reducing design, and products directed to Latin America by simplifying features in order to offer them for sale at low prices. As a result, companies that have large export sales volumes to Latin America usually follow a low price strategy (opposite to Aulakh et al.'s (2000) findings), whereas companies with large sales volumes in the USA usually follow a differentiation strategy based on the augmented product (better service, more product attributes). Exports to the European Union seem to need a mixed-price strategy due to differences in market conditions within the region.

Additionally, there is a very important distinction in the effect of the different components of the promotional strategy to increase export sales. Past literature has shown that advertising informs, reminds and persuades foreign customers about export products and, as a direct result, generates sales (Cateora and Graham, 2002). We have found that this is indeed the case for export sales volume, independent of the final regional export destination. Nevertheless, the positive effect of expenditures in advertising is larger for exports destined to geographically distant markets such Latin America. This also holds true for other elements of the promotional strategy such as fairs and consumer promotions. If the role of the promotional strategy is to inform and persuade foreign customers, then this strategy appears to be more effective in regional destinations that are further away from the domestic market since relationships and knowledge about customers are more difficult to build. Nevertheless, geographically closer markets, such as the European Union, do not show such a significant increase in export sales through attendance to fairs and other promotions. On the other hand, channel development strategies were only significant in the case of the European Union. Past literature has been inconsistent in recognizing the relationship between channel intermediary type and overall export performance (Leonidou et al., 2002). However, it has been identified that intermediary support would lead to better export performance through the development of long term business relationships (Cavusgil and Zou, 1994). In that sense, dealer support would be easier to implement in geographically closer markets. 
Overall, the greater the export experience, firm size and export commitment, the higher the sales volume would be in psychologically distant markets. Export sales volume also depends on implementing the correct marketing strategy for the market destination. The necessary level of adaptation would depend on the cultural, economic and political differences between domestic market conditions and foreign market conditions (O'Grady and Lane, 1996; Conway and Swift, 2000). In that respect, exports to the USA would benefit from augmented products through additional services, exports to Latin America from product simplifications that allow for lower prices, and exports to Eastern Europe from reductions in product design. Finally, although advertising expenditures are always a determinant of export sales, this and other elements of the communication strategy, such as attending fairs and promotions, seem to be more beneficial to improve export sales volumes in geographically distant markets where consumer relationships are not yet established. In geographically closer markets, channel support is much easier to achieve and, as a result, channel development strategies translate more effectively into additional export sales.

\section{Implications for managers and public policy makers}

These findings have important implications for both practice and theory. A company which desires to export abroad has to choose between three different strategic orientations: a domestic market extension orientation, a global marketing orientation, or a multi-domestic market orientation (Cateora and Graham, 2002). Researchers have generally ascribed a firm's positive export performance to implementation of a global marketing orientation instead of simply extending domestic practices internationally (Zou and Cavusgil, 2002). Nevertheless, Samiee and Roth (1992) found no significant relationship between global standardization and a firm's performance. Our findings also support that a standardized global strategy does not lead to strong export performance in each regional market. Marketing strategy has to be adapted to individual market conditions if the objective is to maximize export sales volume. Nevertheless, we have to keep in mind that our findings are specific to sales volume and not other elements of export performance, such as total firm profitability.

Another interesting implication of our findings is that companies have to differentiate between strategies that are inefficient in maximizing sales because they do not act on differences in consumer needs, and strategies that are ineffective because companies do not have the capability to implement them correctly. Product and price adaptation improve sales volume because they respond to cultural and economic differences between target markets (O'Grady and Lane, 1996; Conway and Swift, 2000). Consumers evaluate and shop for products differently across markets and, therefore, would favor different types of product and price adaptations. For example, investing in improving a product's after-sale service will not have an effect in markets where only price competitiveness matters due to reduced ability to pay. On the other hand, we found that investing in distribution networks only significantly affected sales volume for exports directed to the European Union. This finding seems to be due to the fact that physical closeness to distributors improves the company's capability to provide superior dealer support and training, which, in turn, improves channel "push" for sales (Beamish et al., 1993; Cavusgil and Zou, 1994). If physical closeness to the market does not exist, the ability to support distribution channels will be compromised. Therefore, companies' budgets would be more efficiently spent in promotional activities that 
allow for direct contact with the consumer and "pulling" demand instead of investing in sustaining both proprietary and non-proprietary distribution channels.

Finally, public policy administrators and export assistance organizations should provide incentives that seek to change an exporting firm's characteristics in order to improve the probabilities of entering any potential market regardless of its psychological distance. First of all, a minimum firm size is a necessary prerequisite for involvement in any regional market. Publicly supported programs that minimize the burden of hiring additional employees or accessing capital should improve export sales volumes in any region of the world. However, export experience and motivation towards proactive exporting are necessary for firms to expand their sales base in psychologically distant markets. Therefore, emphasis should be placed on providing firms with programs (e.g. subsidies) that reduce their perceived risk of doing business in those markets and increase overall export experience. Additionally, the export promotion administration should also design programs that encourage considering exporting as part of the company's long-term plan and re-structuring the organization to respond to such a long-term plan.

\section{Limitations and future resarch}

There are, unavoidably, a number of limitations in this research. One of them is the data source. The database developed by the Spanish Chamber of Commerce is an extremely valuable resource in studying export strategy in Spain. It measures around 100 different variables and offers information about 13,601 companies in ten different industries. It is difficult to find studies in the literature that have used such a comprehensive database. Nevertheless, it has a number of shortcomings. First of all, the survey instrument was developed with the idea of providing a descriptive view of current export practices without an exploratory analysis in mind. Therefore, the scales for construct measurement were not developed specifically for this study. That could be the reason why some marketing variables that have traditionally been found significant in the literature, such as distribution agreements (Aaby and Slater, 1989; Cavusgil and Zou, 1994; June and Collins-Dodd, 2000), were only found significant for a

limited area of influence. Second, the database does not allow for the analysis of some specific elements in the marketing strategy. For example, we could only analyze price strategy for overall price levels, when other elements of price standardization, such as currency, credit terms or pricing methods have also been shown to have an effect on export performance (Shoham, 1996). Finally, this dataset does not incorporate other indicators of performance, such as profits, market-share, and several non-economic measures. Therefore, we are not able to develop a multidimensional construct of export performance (Katsikeas et al., 2000) and have only referred to the identification of determinants of export sales volume when analyzing the model.

Therefore, a first avenue of future research would be to validate our results through additional data collection in Spain and other countries, both European and not. Our current findings are restricted to Spanish exporting companies within the context of manufacturing and agricultural industries. If replications of the study were carried out in other exporting contexts, we could test the generalizability of the model's results. Additionally, these findings are limited to exporting as an entry mode. A natural extension of this study would be to investigate determinants of international performance when companies use other foreign market entry modes, such as licensing, franchising, and joint ventures. 
It would also be interesting to develop a new survey instrument that includes new variables and new scales to measure former analyzed variables. Such a survey would help validate results and provide richer information to extend our model, improving our understanding of the phenomena. For example, we did not take into consideration situational variables such as specificities in regulations, country-of-origin effects or governmental channel control. These variables could hinder the effectiveness of marketing strategies or totally prevent the use of certain strategies. Additionally, there could be differences in consumer behavior by industry and segment that qualify our current findings. Finally, although we assume that physical and psychological distance to the different regional markets could be a very important source of explanation of our findings, they were not measured as such in our analysis. Further analysis may provide important insights by incorporating measurements of the physical and psychological distance between markets to our framework.

\section{References}

Aaby, N. and Slater, S. (1989), "Management influences on export performance: a review of the empirical literature 1978 1988”, International Marketing Review, Vol. 6 No. 4, pp. 726.

Agarwal, S. and Ramaswami, S.N. (1992), "Choice of foreign market entry mode: impact of ownership, location, and international factors", Journal of International Business Studies, Vol. 23 No. 1, pp. 127.

Amine, L.S. and Cavusgil, S.T. (1986), "Export marketing strategies in the British clothing industry”, European Journal of Marketing, Vol. 20 No. 7, pp. 2133.

Aulakh, P., Kotabe, M. and Teegen, H. (2000), "Export strategies and performance of firms from emerging economies: evidence from Brazil, Chile, and Mexico", Academy of Management Journal, Vol. 43 No. 3, pp. 34261.

Beamish, P.W., Craig, R. and McLellan, K. (1993), "The performance characteristics of Canadian versus UK exporters in small and medium sized firms", Management International Review, Vol. 33 No. 2, pp. 12137.

Benito, G. and Gripsrud, G. (1992), "The expansion of foreign direct investment: discrete rational location choices or a cultural learning process?”, Journal of International Business Studies, Vol. 23 No. 3, pp. 46176.

Bilkey, W.J. (1978), "An attempted integration of the literature on the export behavior of firms", Journal of International Business Studies, Vol. 9 No. 1, pp. 3346.

Bilkey, W.J. (1982), "Variables associated with export profitability", Journal of International Business Studies, Vol. 13 No. 2, pp. 3955.

Bilkey, W.J. (1985), "Development of export marketing guidelines", International Marketing Review, Vol. 2 No. 1, pp. 3140.

Brouthers, K.D. and Brouthers, L.E. (2001), "Explaining the national cultural distance paradox", Journal of International Business Studies, Vol. 32 No. 1, pp. 17789.

Burton, F.N. and Schlegelmilch, B.B. (1987), "Profile analyses of non exporters versus exporters grouped by export involvement", Management International Review, Vol. 27 No. 1, pp. 3849.

Cateora and Graham (2002), International Marketing, McGraw Hill, New York, NY.

Cavusgil, S.T. (1984a), "Differences among exporting firms based on their degree of internationalization”, Journal of Business Research, Vol. 12 No. 3, pp. 195208. 
Cavusgil, S.T. (1984b), "Organizational characteristics associated with export activity”, Journal of Management Studies, Vol. 21 No. 1, pp. 322.

Cavusgil, S.T. and Kirpalani, W.H. (1993), "Introducing products into export markets: success factors", Journal of Business Research, Vol. 27 No. 1, pp. 115.

Cavusgil, S.T. and Nevin, J.R. (1981), "Internal determinants of export marketing behaviour: an empirical investigation", Journal of Marketing Research, February, pp. 11436.

Cavusgil, S.T. and Zou, S. (1994), "Marketing strategy performance relationship: an investigation of the empirical link in export market ventures", Journal of Marketing, Vol. 58 No. 1, pp. 121.

Cavusgil, S.T., Bilkey, W.J. and Tesar, G. (1979), "A note on the export behavior of firms: exporter profiles”, Journal of International Business Studies, Vol. 10, Spring/Summer, pp. 917.

Cavusgil, S.T., Zou, S. and Naidu, G.M. (1993), "Product and promotion adaptation in export ventures: an empirical study", Journal of International Business Studies, Vol. 24 No. 3, pp. 47999.

Christensen, C., da Rocha, A. and Gertner, R.K. (1987), "An empirical investigation of the factors influencing exporting success of Brazilian firms", Journal of International Business Studies, Vol. 18, Fall, pp. 6178.

Conway, T. and Swift, J. (2000), "International relationship marketing. The importance of psychic distance”, European Journal of Marketing, Vol. 34 No. 11/12, pp. 1391413.

Cooper, R.G. and Kleinschmidt, E.J. (1985), "The impact of export strategy on export sales performance”, Journal of International Business Studies, Vol. 16 No. 1, pp. 3755.

Cunningham, M.T. and Spiegel, R.I. (1971), "A study in successful exporting”, European Journal of Marketing, Vol. 5, Spring, pp. 211.

Czinkota, M. and Johnston, W.J. (1981), "Segmenting US firms for export development", Journal of Business Research, Vol. 9 No. 4, pp. 35363.

Czinkota, M.R. and Johnston, W.J. (1983), "Exporting: does sales volume make a difference?”, Journal of International Business Studies, Vol. 14 No. 1, pp. 14753.

Czinkota, M. and Lalonde (1980), "The role of physical distribution in the export activity of US manufacturing firms", International Journal of Physical Distribution \& Materials Management, Vol. 11 No. 5, pp. 513.

Dean, D., Menguç, B. and Myers, C.P. (2000), "Revisiting firm characteristics, strategy, and export performance relationship: a survey of the literature and an investigation of New Zealand small manufacturing firms", Industrial Marketing Management, Vol. 29 No. 5, pp. 46177.

Diamantopoulos, A. and Inglis, K. (1988), "Identifying differences between high and low involvement exporters", International Marketing Review, Vol. 5 No. 2, pp. 5260.

Dominguez, L.V. and Sequeira, C.G. (1993), "Determinants of LDC exporters' performance: a cross national study", Journal of International Business Studies, Vol. 24, 1st quarter, pp. 1940.

Douglas, S.P. and Craig, C.S. (1989), "Evolution of global marketing strategy: scale, scope, and synergy", Columbia Journal of World Business, Vol. 24 No. 3, pp. 4759.

Douglas, S.P. and Craig, C.S. (1992), International Marketing Research, Prentice Hall, Englewood Cliffs, NJ.

Douglas, S.P. and Wind, Y. (1987), "The myth of globalisation", Columbia Journal of World Business, Vol. 24 No. 3, pp. 1930. 
Dow, D. (2000), “A note on psychological distance and export market selection”, Journal of International Marketing, Vol. 8 No. 1, pp. 5164.

Evans, J., Treadgold, A. and Mavondo, F. (2000), "Comment: explaining export development through psychic distance”, International Marketing Review, Vol. 17 No. 2, pp. 1648.

Fraser, C. and Hite, R. (1990), "Impact of international marketing strategies on performance in diverse global markets”, Journal of Business Research, Vol. 20, pp. 24962.

Ghemawat, P. (2001), "Distance still matters: the hard reality of global expansion", Harvard Business Review, September, pp. 311.

Gripsrud, G. (1990), "The determinants of export decisions and attitudes to a distant market: Norwegian fisher exports to Japan”, Journal of International Business Studies, 3rd quarter, pp. 46985.

Gupta, N. (1980), "Some alternative definitions of size", Academy of Management Journal, Vol. 23 No. 4, pp. 75966.

Haar, J. and Ortiz Buonafina, M. (1995), "The international process and marketing activities. The case of Brazilian export firms", Journal of Business Research, Vol. 32, pp. 17581.

Hofstede, G. (1980), Culture's Consequences: International Differences in Work related Values, Sage Publications, Beverly Hills, CA.

Hubbard, R. and Armstrong, J. (1994), "Replications and extension in marketing: rarely published but quite contrary", International Journal of Research in Marketing, Vol. 11, pp. 23348.

Hubbard, R., Vetter, D. and Little, E. (1998), "Replication in strategic management: scientific testing for validity, generalizability and usefulness", Strategic Management Journal, Vol. 19 No. 3, pp. 24354.

Johanson, J. and Vahlne, J. E. (1977), "The internationalisation process of the firm a model of knowledge development and increasing foreign commitments", Journal of International Business Studies, Vol. 8 No. 1, pp. 2332.

Johanson, J. and Vahlne, J. (1990), "The mechanism of internationalisation", International Marketing Review, Vol. 7 No. 4, pp. 1124.

June, F. and Collins Dodd, C. (2000), "The impact of firms' export orientation on the export performance of high tech small and medium sized enterprises", Journal of International Marketing, Vol. 8 No. 3, pp. 8497.

Katsikeas, C.S. (1994), "Export competitive advantages: the relevance of firm characteristics", International Marketing Review, Vol. 11 No. 3, pp. 3356.

Katsikeas, C.S. and Piercy, N.F. (1990), “The relationship between Greek export manufacturers and UK importers: the dimension of exercised power", Journal of Marketing Management, Vol. 6 No. 3, pp. 23956.

Katsikeas, C.S. and Piercy, N.F. (1993), "Long term export stimuli and firm characteristics in a European LDC", Journal of International Marketing, Vol. 1 No. 3, pp. 2347.

Katsikeas, C., Leonidou, C.L. and Morgan, N. (2000), "Firm level export performance assessment: review, evaluation, and development", Journal of the Academy of Marketing Science, Vol. 28 No. 4, pp. 493511.

Kaynak, E. and Kuan, W.K. (1993), "Government, strategy, structure, and performance in the context of export activity: an empirical study of Taiwanese manufacturing firms", Journal of Business Research, Vol. 27 No. 1, pp. 3349.

Kirpalani, H. and Macintosh, B. (1980), "International marketing effectiveness of technology oriented small firms", Journal of International Business Studies, Vol. 11 No. 3, pp. 8190. 
Klein, S. and Roth, V. (1990), "Determinants of export channel structure: the effects of experience and psychic distance reconsidered", International Marketing Review, Vol. 7 No. 5, pp. 2738.

Kogut, B. and Singh, H. (1988), "The effect of national culture on the choice of entry mode", Journal of International Business Studies, Vol. 19 No. 3, pp. 41132.

Leonidou, L.C. (1995), "Export stimulation research: review, evaluation, and integration", International Business Review, Vol. 4 No. 2, pp. 13356.

Leonidou, L.C. (1998), "Organizational determinants of exporting: conceptual, methodological, and empirical insights", Management International Review, Vol. 38 No. 1, pp. 752.

Leonidou, L.C. and Katsikeas, C.S. (1996), "The export development process: an integrative review of empirical models", Journal of International Business Studies, Vol. 27 No. 3, pp. 51751.

Leonidou, L.C., Katsikeas, C.S. and Samiee, S. (2002), "Marketing strategy determinants of export performance: a meta analysis", Journal of Business Research, Vol. 55, pp. 5167.

Louter, P.J., Ouwerkerk, C. and Bakker, B.A. (1991), "An inquiry into successful exporting”, European Journal of Marketing, Vol. 25 No. 6, pp. 723.

McGuiness, N.W. and Little, B. (1981), "The influence of product characteristics on the export performance of new industrial products", Journal of Marketing, Vol. 45 No. 2, pp. 11022.

Madsen, T.K. (1989), "Successful export marketing management: some empirical evidence", International Marketing Review, Vol. 6 No. 4, pp. 4157.

Mitra, D. and Golder, P. (2002), "Whose culture matters? Near market knowledge nad its impact on foreign market entry timing", Journal of Marketing Research, Vol. 39 No. 3, pp. 35065.

Nordstrom, K.A. (1991), "The internationalization process of the firm: searching for new patterns and explanations", doctoral dissertation, Stockholm School of Economics, Stockholm.

O'Grady, S. and Lane, H. (1996), "The psychic distance paradox", Journal of International Business Studies, Vol. 27 No. 2, pp. 30933.

Piercy, N. (1981), “Company internationalization: active and reactive exporting”, European Journal of Marketing, Vol. 15 No. 3, pp. 2640.

Reid, S.D. (1981), "The decision maker and export expansion”, Journal of International Business Studies, Vol. 12 No. 2, pp. 10112.

Rosson, P.J. and Ford, I.D. (1982), "Manufacturer overseas distributor relations and export performance", Journal of International Business Studies, Vol. 13 No. 2, pp. 5773.

Samiee, S. and Roth, K. (1992), "The influence of global marketing standardization on performance", Journal of Marketing, Vol. 56 No. 4, pp. 112.

Seringhaus, F.H.R. and Rosson, P.J. (1998), "Management and performance of international trade fair exhibitors: government stands vs independent stands", International Marketing Review, Vol. 15 No. 5, pp. 398412.

Sethi, P.S. (1971), “Comparative cluster analysis for world markets", Journal of Marketing Research, Vol. 8, August, pp. 34854.

Shenkar, O. (2001), "Cultural distance revisited: towards a more rigorous conceptualization and measurement of cultural differences", Journal of International Business Studies, Vol. 32 No. 3, pp. 51935.

Shoham, A. (1996), "Marketing mix standardization: determinants of export performance", Journal of Global Marketing, Vol. 10 No. 2, pp. 5373.

Steenkamp, J. (2001), "The role of national culture in international marketing research", International Marketing Review, Vol. 18 No. 1, pp. 3144. 
Stottinger, B. and Schlegelmilch, B.B. (1998), "Explaining export development through psychic distance: enlightening or elusive?", International Marketing Review, Vol. 15 No. 5, pp. 35772.

Styles, C. and Ambler, T. (1994), "Successful export practice: the UK experience", International Marketing Review, Vol. 11 No. 6, pp. 2347.

Van Den Bulcke, D. (1986), "Role and structure of Belgian multinationals", in Macharzina, K. and Staehle, W.H. (Eds), European Approaches to International Management, De Gruyter, New York, NY.

WTO (2002), Annual Report 2002, World Trade Organization, France.

Yaprak, A. (1985), "An empirical study of the differences between small exporting and non exporting US firms", International Marketing Review, Vol. 2 No. 2, pp. 7283.

Yeoh, P. and Jeong, I. (1995), "Contingency relationships between entrepreneurship and export channel structure and environment: a proposed model of export performance", European Journal of Marketing, Vol. 29 No. 8, pp. 95115.

Zou, S. and Cavusgil, T. (2002), "The GMS: a broad conceptualization of global marketing strategy and its effect on firm performance", Journal of Marketing, Vol. 66 No. 4, pp. 4056.

Zou, S. and Stan, S. (1998), "The determinants of export performance: a review of the empirical literature between 1987 and 1997", International Marketing Review, Vol. 15 No. 5, pp. 33356 .

\section{Further reading}

Douglas, S.P. and Craig, C.S. (1983), International Marketing Research, Prentice Hall, Englewood Cliffs, NJ

Kleinschmidt, E. and Cooper, R.G. (1988), "The performance impact of an international orientation on product innovation", European Journal of Marketing, Vol. 22 No. 10, pp. 5671.

Naidu, G.M. and Prasad, V.K. (1994), "Predictions of export strategy and performance of small and medium sized firms", Journal of Business Research, Vol. 31 No. 1/2, pp. 10715. 